\title{
Appearance of Triacylglycerol Lipase in Egg Yolk Sac of Japanese Quail during Embryonic Development, Its Partial Purification and Some Properties
}

\author{
Makoto FujII, Itsuko Horizoe, Takao FukunaGA \\ Katsuya Koga and Yasuo Aizono* \\ Department of Animal Science, Faculty of Agriculture, Kagoshima University, \\ Kagoshima 890, Japan \\ * Laboratory of Biological Chemistry, Faculty of Agriculture, \\ Kyushu University, Fukuoka 812, Japan
}

Received August 28, 1985

\begin{abstract}
Triacylglycerol lipase activity appeared on the 8th day of embryonic development of the Japanese quail in the egg yolk sac and its contents, and activity was highest on the 12th day, although yolk lipids decreased markedly at the later stage of embryonic development. We extracted the lipase from the defatted yolk sac of 12-day eggs, purified it to a 200 -fold specific activity. This purified preparation gave at least 2 bands having hydrolyzing activity against $\beta$-naphthylbutyrate upon polyacrylamide gel electrophoresis, with molecular weights of 55,000 and 57,000. The enzyme had maximum activity at $\mathrm{pH} 8.0$ and $38^{\circ} \mathrm{C}$. Concerning substrate specificity, the enzyme hydrolyzed a variety of triglycerides, but had the highest specificity for tributyrin. This lipase had some heterogenous forms on isoelectric focusing, with pI values of 4.8 to 5.2. The profile of isoelectric focusing was changed by neuraminidase treatment, showing that sialic acid content affects the net charge of the lipase molecules.
\end{abstract}

The developing chick embryo uses the egg contents as its source of nutrients. Most of the lipids in the yolk are consumed at later stages of embryonic development. ${ }^{1)}$ Several studies on lipolytic enzymes in embryonic tissues of chicks have been done. ${ }^{2,3)}$ Bengtsson et al. ${ }^{4)}$ found lipolytic enzymes in embryonic tissues but not in the yolk or the yolk sac. They suggested that yolk lipids in lipoproteins were hydrolyzed in the embryonic tissues after they passed into the circulation fluid of the embryo from the yolk. However, the mechanism of transfer of lipid from the yolk to the embryo via the circulating fluid is unknown. During our study of lipolytic enzymes in the egg yolk of Japanese quail, we found that phospholipase appears in the egg yolk sac during embryonic development. ${ }^{5)}$ So did triacylglycerol lipase. Here, we wanted to purify the lipase in order to characterize it.

\section{MATERIALS AND METHODS}

Fertilized eggs of the Japanese quail (Coturnix coturnix japonica) were incubated at $38^{\circ} \mathrm{C}$. The yolk sacs and their contents were taken from the eggs after $2,4,6,8,10,12$, 14 , and 16 days of incubation. These sacs and contents from 24 eggs at each stage were pooled and divided in half to assay the amount of lipid by the method of Folch et al. ${ }^{6)}$ and for enzyme assay. DEAE-cellulose was purchased from Brown Co., and Sephadex G-75 and Sepharose 4B from Pharmacia Fine Chemicals. Commercial triacylglycerols used as substrate for lipase were purified by Florisil column chromatography, ${ }^{77}$ and the purity was monitored by silica gel G-60 thin-layer chromatography as described elsewhere. ${ }^{8)}$ Isoelectric focusing was done using $1 \%$ carrier ampholyte $(\mathrm{v} / \mathrm{v})$ covering the $\mathrm{pH}$ range of $4 \sim 6$ in a $110-\mathrm{ml}$ column, as directed in the instruction manual supplied by LKB. The voltage was maintained at $400 \mathrm{~V}$ for the first $10 \mathrm{hr}$ and at $1000 \mathrm{~V}$ for the next $30 \mathrm{hr}$. Fractions of $1.5 \mathrm{ml}$ were collected and the $\mathrm{pH}$ and lipolytic activity were measured. Gel isoelectric focusing was done in a $4 \%$ polyacrylamide gel with a $\mathrm{pH}$ gradient of $3 \sim 10$. The molecular weight was calculated from the results of polyacrylamide gel electrophoresis as described by Hedrick and Smith. ${ }^{9}{ }^{9}$ 
Preparation of glyceric acid- $C_{6}$-Sepharose $4 B$. Twenty grams of Sepharose $4 \mathrm{~B}$ activated with cyanogen bromide was coupled with $2.8 \mathrm{~g}$ of 1,6-diaminohexane as spacer at pH 10 and $4{ }^{\circ} \mathrm{C}$ overnight. After the gel derivative was washed with water and $1 \mathrm{~m} \mathrm{NaCl}, 1 \mathrm{~g}$ of glyceric acid was coupled to the gel using $0.6 \mathrm{~g}$ of 1-ethyl-3-(3dimethylaminopropyl)-carbodiimide hydrochloride as catalyst. The gel was washed successively with water, $1 \mathrm{M}$ $\mathrm{NaCl}$, and $1 \%$ Triton $\mathrm{X}-100$, packed into a column, and equilibrated with $0.01 \mathrm{M}$ Tris- $\mathrm{HCl}$ buffer, $\mathrm{pH} 7.5$.

Extraction of lipase. The yolk sacs and contents from eggs incubated for various periods were defatted with $5 \mathrm{vol}$ (v/w) of acetone 3 times, and then ethyl ether-methanol $(1: 1, v / v) 5$ times, using a Waring blender. The lipase was extracted from the defatted yolk powder with $10 \mathrm{vol}(\mathrm{v} / \mathrm{w})$ of $0.01 \mathrm{M}$ Tris- $\mathrm{HCl}$ buffer ( $\mathrm{pH} 8.0$ ) using a glass homogenizer. After centrifugation at $8000 \times g$ for $30 \mathrm{~min}$, the precipitate was homogenized again in the same buffer and the suspension was centrifuged. To the collected supernatant was added solid ammonium sulfate to $65 \%$ saturation. After centrifugation at $5000 \times g$ for $15 \mathrm{~min}$, the precipitate was dialyzed against distilled water and used as the crude lipase. All experiments were done at $4^{\circ} \mathrm{C}$.

Assay of lipase activity. The lipase activity was assayed using two methods.

Method 1. Lipase activity was assayed colorimetrically using Rhodamine 6G. ${ }^{10}$ ) The assay mixture consisted of $0.1 \mathrm{ml}$ of $5 \%$ tributyrin in $1 \%$ Tween $60,0.4 \mathrm{ml}$ of $0.1 \mathrm{M}$ Tris- $\mathrm{HCl}$ buffer ( $\mathrm{pH} 8.0$ ), a portion of enzyme solution, and sufficient deionized water in a total volume of $1.0 \mathrm{ml}$. After incubation at $38^{\circ} \mathrm{C}$ for $30 \mathrm{~min}$, the reaction was stopped by adding $3 \mathrm{ml}$ of heptane-isopropyl alcohol- $1 \mathrm{~N}$ $\mathrm{H}_{2} \mathrm{SO}_{4}(10: 40: 1$, by vol.), followed by addition of $2 \mathrm{ml}$ of water and $3 \mathrm{ml}$ of heptane. The mixture was vigorously shaken and left at $4^{\circ} \mathrm{C}$ for $3 \mathrm{hr}$. After centrifugation at $1000 \times g$ for $5 \mathrm{~min}, 2 \mathrm{ml}$ of the heptane layer was mixed with $1 \mathrm{ml}$ of Rhodamine $6 \mathrm{G}$ reagent, and the absorbance was measured at $515 \mathrm{~nm}$. The value was corrected for the extraction efficiency of each fatty acid constituting the triglycerides used as the substrate, because this efficiency changed with the length of the carbon-chain of the fatty acid. When olive oil was the substrate, the efficiency for oleic acid was used. Tween 60 used as the triglyceride emulsifier was little hydrolyzed by the lipase.

Method 2. Lipase activity was assayed by titration of released fatty acid with $0.02 \mathrm{~N} \mathrm{NaOH}$ on a $\mathrm{pH}$ stat (Tooa Denpa Co., model HSM-10A) at $\mathrm{pH} 8.0$ and $38^{\circ} \mathrm{C}$.

In this study, tributyrin was used as the substrate unless otherwise noted, since the yolk lipase effectively hydrolyzed triacylglycerol with short-carbon-chain fatty acids. One unit of enzyme was defined as the amount of enzyme releasing $1 \mathrm{nmol}$ of fatty acid per minute. The amount of protein was assayed by the absorbance at $280 \mathrm{~nm}$.

\section{RESULTS}

\section{Appearance of lipase activity in egg yolk}

The total lipid in the yolk decreased markedly at later stages of embryonic development, in parallel with the decrease in yolk weight (Fig. 1). Lipase activity appeared on the 8th day of incubation, and activity was highest on the 12th day of incubation, in contrast to the decrease in lipids in the yolk. For this reason, we extracted the enzyme from the egg yolk and yolk sac of eggs incubated for 12 days at $38^{\circ} \mathrm{C}$.

\section{Purification procedure}

The crude lipase was chromatographed on a DEAE-cellulose column in $0.01 \mathrm{M}$ Tris- $\mathrm{HCl}$ buffer ( $\mathrm{pH} 8.0$ ). Most of the lipase activity was in fractions eluted with $0.15 \mathrm{M} \mathrm{NaCl}$ in the same buffer. The enzyme was precipitated by saturation with solid ammonium sulfate. After dialysis against $0.01 \mathrm{~m}$ phosphate buffer $(\mathrm{pH}$ 6.0 ), the fraction was applied to a hydroxylapatite column equilibrated with $0.01 \mathrm{M}$ phosphate buffer $(\mathrm{pH} \mathrm{6,5).} \mathrm{The} \mathrm{activity} \mathrm{was} \mathrm{eluted}$ with $0.15 \mathrm{~m}$ phosphate buffer $(\mathrm{pH}$ 6.5). The lipase was precipitated by salting-out with ammonium sulfate. After dialysis against $0.01 \mathrm{M}$ Tris- $\mathrm{HCl}$ buffer $(\mathrm{pH} 8.0)$, the enzyme

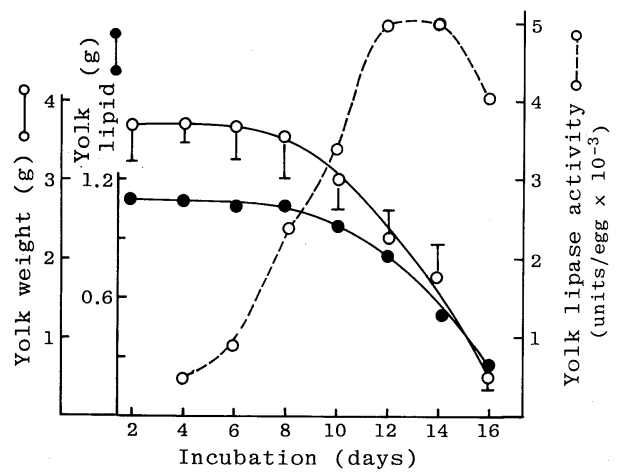

FIG. 1. Changes in the Weights of yolk and Yolk Lipids, and in Lipase Activity during Embryonic Development of the Japanese Quail.

Fertilized eggs were incubated at $38^{\circ} \mathrm{C}$ for the period indicated. The yolk weight is the mean of 12 eggs and bars indicate the S.D. The weight of the total lipid in the yolk and triacylglycerol lipase activity are means of 2 experiments. 


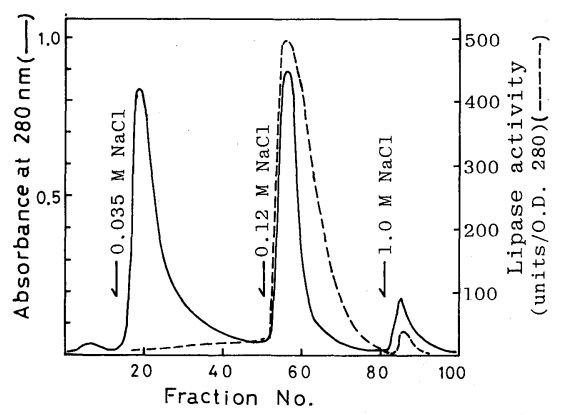

FIG. 2. Glyceric Acid- $\mathrm{C}_{6}$-Sepharose 4B Column Chromatography.

The lipase fractions from Sephadex G-75 gel filtration were put on a column of a Sepharose 4B derivative (see Materials AND Methods) equilibrated with $0.01 \mathrm{M}$ Tris$\mathrm{HCl}$ buffer ( $\mathrm{pH}$ 7.5). Protein adsorbed on the column was eluted by changing the concentration of $\mathrm{NaCl}$ in the buffer. Column size, $1.2 \times 17 \mathrm{~cm}$; flow rate, $20 \mathrm{ml} / \mathrm{hr}$; fract. vol. $4 \mathrm{ml}$.

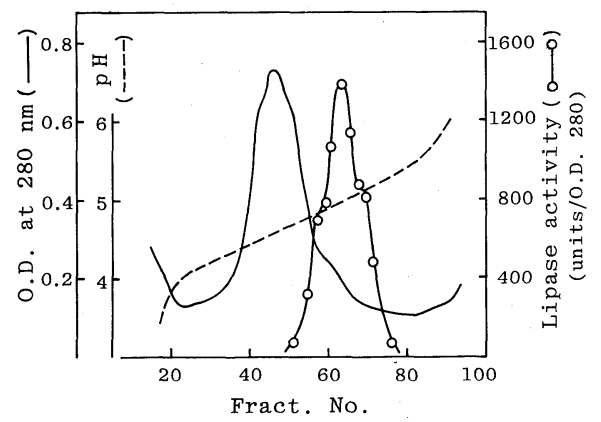

FIG. 3. Isoelectric Focusing of the Lipase.

The lipase fractions from Sepharose 4B derivative affinity chromatography were dialysed against distilled water and subjected to isoelectric focusing (see MATERIALS AND Methods). solution was subjected to a gel filtration through a Sephadex G-75 column in $0.01 \mathrm{~m}$ Tris- $\mathrm{HCl}$ buffer ( $\mathrm{pH}$ 8.0). Most of the activity was eluted as a single peak. The enzyme fractions were concentrated with a collodion membrane filter under reduced pressure. The lipase preparation was subjected to column chromatography with a Sepharose 4B derivative, glyceric acid- $\mathrm{C}_{6}$-Sepharose 4B (Fig. 2). Most of the activity was eluted with $0.01 \mathrm{M}$ Tris $-\mathrm{HCl}$ buffer $(\mathrm{pH}$ 7.5) containing $0.12 \mathrm{M} \mathrm{NaCl}$. The enzyme fractions were concentrated with a collodion membrane filter under reduced pressure, and was subjected to ioelectric focusing from $\mathrm{pH} 4$ to 6 . The profile of activity shows the heterogeneity of

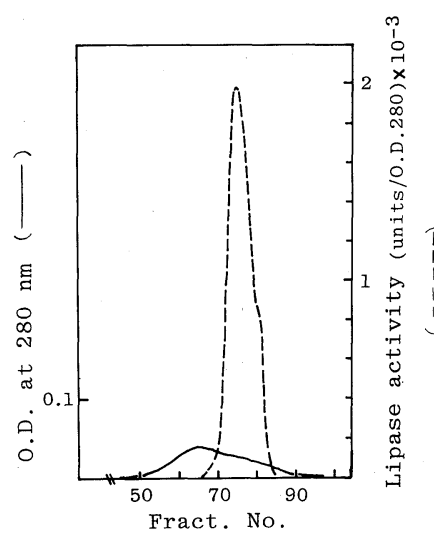

Fig. 4. Second Sephadex G-75 Gel Filtration.

The enzyme from isoelectric focusing was dialysed against $0.01 \mathrm{M}$ Tris- $\mathrm{HCl}$ buffer $(\mathrm{pH} 8.0)$ and applied to a Sephadex G-75 column $(2.6 \times 85 \mathrm{~cm})$ equilibrated with the same buffer. Fract. vol, $3 \mathrm{ml}$ : flow rate, $30 \mathrm{ml} / \mathrm{hr}$.

Table I. Purification Steps

\begin{tabular}{|c|c|c|c|c|c|}
\hline \multirow{3}{*}{ Step } & \multicolumn{2}{|c|}{ Protein } & \multicolumn{3}{|c|}{ Lipase activity } \\
\hline & \multirow{2}{*}{ Total OD 280} & \multirow{2}{*}{ Yield $(\%)$} & \multirow{2}{*}{$\begin{array}{l}\text { Specific activity } \\
\text { (units/OD 280) }\end{array}$} & \multicolumn{2}{|c|}{ Total activity } \\
\hline & & & & Units & Yields $(\%)$ \\
\hline \multicolumn{6}{|l|}{ Crude lipase } \\
\hline (Crude extract) & 26800 & 100 & 56.6 & $152 \times 10^{4}$ & 100 \\
\hline DEAE-cellulose & 9360 & 34.9 & 103.2 & $97 \times 10^{4}$ & 64 \\
\hline Hydroxylapatite & 2340 & 8.7 & 266.4 & $62 \times 10^{4}$ & 41 \\
\hline Sephadex G-75 (first) & 560 & 2.1 & 566.1 & $32 \times 10^{4}$ & 21 \\
\hline GlyOH-C 6 -Sepharose & 168 & 0.6 & 965.7 & $16 \times 10^{4}$ & 11 \\
\hline Isoelectric focusing & 1.5 & 0.006 & 7326.0 & $11 \times 10^{4}$ & 0.7 \\
\hline Sephadex G-75 (second) & 0.7 & 0.003 & 9350 & $6.5 \times 10^{4}$ & 0.4 \\
\hline
\end{tabular}




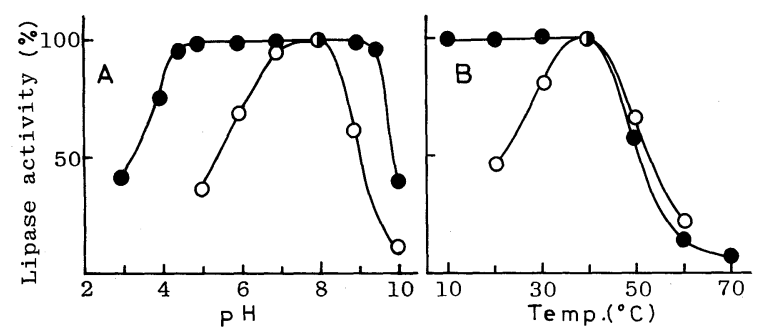

FIG. 5. Effects of $\mathrm{pH}$ and Temperature on Activity and Stability of Lipase.

(A) Effect of $\mathrm{pH}$. The lipase activity was assayed at different $\mathrm{pH}$ using $0.05 \mathrm{~m}$ citrate- $0.1 \mathrm{~m}$ disodium phosphate ( $\mathrm{pH} 3.0 \sim 7.0$ ), $0.1 \mathrm{M}$ Tris-HCl buffer ( $\mathrm{pH} 8.0 \sim 9.0$ ), and $0.1 \mathrm{M}$ carbonate buffer ( $\mathrm{pH} 9.0 \sim 10.0$ ). To examine the $\mathrm{pH}$ stability, the enzyme was incubated for $10 \mathrm{hr}$ at $4^{\circ} \mathrm{C}$ at different $\mathrm{pH}$ using the buffers described above, and then each solution was dialysed against $0.01 \mathrm{~m}$ Tris- $\mathrm{HCl}$ buffer $(\mathrm{pH} 8.0)$ for $40 \mathrm{hr}$ at $4^{\circ} \mathrm{C}$. The remaining activity was assayed. $\mathrm{O}-\mathrm{O}$, optimum $\mathrm{pH}$; $-\mathrm{pH}$ stability.

(B) Effect of temperature. The activity was assayed at different temperatures at $\mathrm{pH} \mathrm{8.0.} \mathrm{To} \mathrm{examine} \mathrm{the}$ thermal stability, the enzyme was incubated at different temperatures at $\mathrm{pH} 8.0$ for $30 \mathrm{~min}$, and cooled rapidly on ice. The remaining activity was assayed. $\bigcirc-\bigcirc$, optimum temperature; - , thermal stability.

Table II. Effects of Additions on Lipase Activity

\begin{tabular}{lcc}
\hline Addition & Concentration & Activity (\%) \\
\hline None & - & 100 \\
$\mathrm{CaCl}_{2}$ & $1 \mathrm{~mm}$ & 94 \\
& $10 \mathrm{~mm}$ & 101 \\
EDTA & 1 & 102 \\
$\mathrm{NaCl}$ & 100 & 90 \\
PCMB* & 1 & 98 \\
2-Mercaptoethanol & 1 & 103 \\
Protamine sulfate & 1 & 65 \\
Heparin & $0.1 \%$ & 90 \\
Bovine serum albumin & $0.5 \%$ & 125 \\
Triton X-100 & $0.1 \%$ & 90 \\
\hline
\end{tabular}

Lipase activity was assayed with addition by the Rhodamine $6 \mathrm{G}$ method using tributyrin as a substrate.

* $\rho$-Chloromercuribenzoate.

the lipase protein (Fig. 3). Fractions having the lipase activity were pooled and purified by a second Sephadex G-75 gel filtration (Fig. 4). Typical results from each step of purification are given in Table I.

\section{Some properties of purified enzyme}

The lipase activity was linear up to $30 \mathrm{~min}$. The optimum $\mathrm{pH}$ for the enzyme was 8.0 (Fig. $5 \mathrm{~A})$ and the optimum temperature about $38^{\circ} \mathrm{C}$ at that $\mathrm{pH}$ (Fig. 5B). The enzyme was stable below $40^{\circ} \mathrm{C}$, and also over the $\mathrm{pH}$ range of 4.5 to 9.5. Its lipolytic activity against tributyrin was not affected by $\mathrm{CaCl}_{2}$, EDTA, PCMB, $\mathrm{NaCl}$, Triton X-100, or heparin (Table II).
Table III. Substrate Specificity of the Lipase

\begin{tabular}{lc}
\hline Substrate & Activity $(\%)$ \\
\hline Triacetin & $23^{a}$ \\
Tributyrin & $100^{a, b}$ \\
Tricaproin & $43^{a}$ \\
Tricaprin & $17^{a}$ \\
Trimyristin & $14^{b}$ \\
Triolein & $7^{b}$ \\
Olive oil & $10^{b}$ \\
Phosphatidylcholine & $11^{a}$ \\
Methyl butyrate & $8^{a}$ \\
$\beta$-Naphthyl butyrate & 315 \\
$\beta$-Naphthyl palmitate & 8 \\
\hline
\end{tabular}

The hydrolysis rates of substrates were expressed as percentages of that of tributyrin. The enzyme activity on acyl- $\beta$-naphthol was assayed using the method of Nachlas and Seligman. ${ }^{11)}$

a The value was obtained by the alkaline titration method.

$b$ The value was obtained by the Rhodamin $6 \mathrm{G}$ method.

Protamine sulfate decreased the activity. The enzyme was activated by bovine serum albumin by $25 \%$. Concerning substrate specificity, the enzyme hydrolyzed a variety of triglycerides, but had the highest specificity for tributyrin (Table III). The enzyme also had high activity with $\beta$-naphthylbutyrate but low activity with $\beta$-naphthylpalmitate. Polyacrylamide gel electrophoresis gave at least two major bands having hydrolytic activity against $\beta$-naphthylbutyrate (Fig. 6A). The 


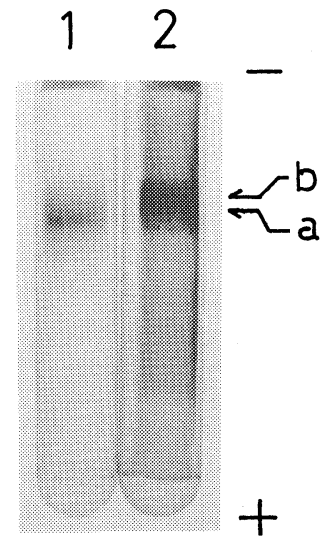

(A)

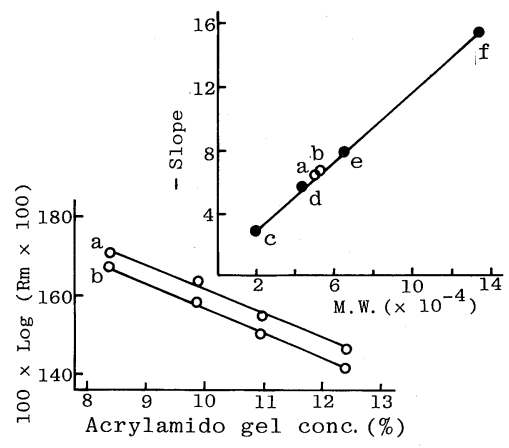

(B)

FIG. 6. (A) Polyacrylamide Gel Electrophoresis of Lipase.

The lipase was subjected to polyacrylamide gel $(10 \%)$ electrophoresis. Protein was stained with Amido Black 10 B (lane 1). Acyl-hydrolyzing activity was detected by staining the gel with $\beta$-naphthyl butyrate and Fast Violet salt B (lane 2).

(B) Estimation of the Molecular Weights of the Lipases (a and $b$ ).

The lipase and the standard proteins were subjected to polyacrylamide gel electrophoresis with different gel concentrations from $8.5 \sim 12.5 \%$ at $\mathrm{pH} 8.9$. The acylhydrolyzing activity was detected as described above. Slopes for the marker proteins and the enzymes ( $a$ and $b$ ) were calculated from plots of log relative mobility versus the percentage of the gel concentration. The marker proteins were: c, soybean trypsin inhibitor (MW 20,000); d, ovalbumin (MW 45,000); e, bovine serum albumin monomer (MW 67,000); and f, bovine serum albumin dimer (MW 134,000). The open circles ( $a$ and $b$ ) indicate the two acyl-hydrolyzing activities on $\beta$-naphthylbutyrate.

molecular weight of the major active bands were calculated to be 55,000 and 57,000 (Fig. $6 \mathrm{~B})$ respectively, by the method of Hedrick

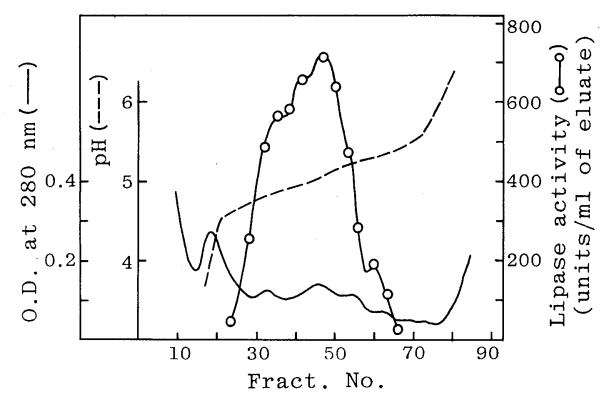

FIG. 7. Second Isoelectric Focusing of the Lipase.

Carrier ampholite covering a narrow $\mathrm{pH}$ range of $4.5 \sim 5.5$ was obtained by isoelectric focusing beforehand of the ampholite covering the $\mathrm{pH}$ from 4.0 to 6.0. The lipase was subjected to the isoelectric focusing using this ampholite. Other conditions are given in Materials AND Methods.

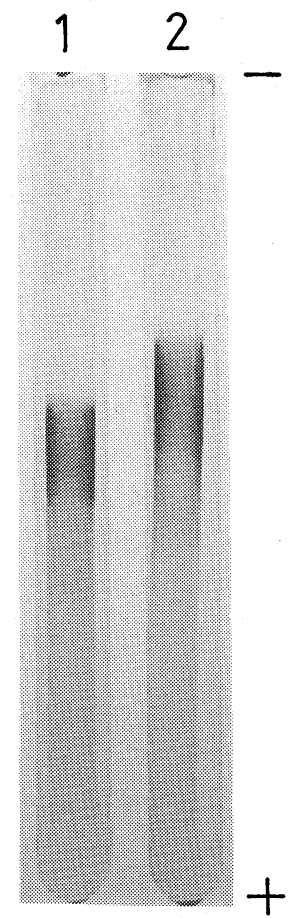

FIG. 8. Gel Isoelectric Focusing of Lipases with and without Neuraminidase.

The lipases with and without neuraminidase treatment ( 0.5 units) for $3 \mathrm{hr}$ at $25^{\circ} \mathrm{C}$ was subjected to polyacrylamide gel $(4 \%)$ isoelectric focusing using ampholite covering the $\mathrm{pH}$ range of $3 \sim 10$. Lane 1 , lipase not treated with neuraminidase; lane 2 , lipase treated with neuraminidase.

and Smith. ${ }^{9)}$

To examine the $\mathrm{pI}$ value of the enzyme, the preparation was studied by isoelectric focusing from $\mathrm{pH} 4.5$ to 5.5 . The enzyme was micro- 
heterogeneous with $\mathrm{pI}$ values of 4.8 to 5.2 (Fig. 7).

When the enzyme was treated with neuraminidase for $3 \mathrm{hr}$ at $25^{\circ} \mathrm{C}$, its $\mathrm{pI}$ shifted to alkaline $\mathrm{pH}$, judged by isoelectric focusing in polyacrylamide gel (Fig. 8).

\section{DISCUSSION}

We dealt here with the appearance of lipase activity in the egg yolk sac and contents during embryonic development of the Japanese quail, and with its purification.

The lipids in the yolk decreased greatly at the later stages of embryonic development of the Japanese quail, in agreement with the report on hen egg by Noble and Moore. ${ }^{1)}$ The marked increase in lipase activity in the yolk sac at the later stages of embryonic development was very similar to that of phospholipase $\mathrm{C}$ activity in the yolk sac at the same stage. ${ }^{5)}$ Phospholipase A activity also increased at the same stage (data not shown). The marked increases in these lipolytic enzyme activities corresponded well to the marked decrease in the lipid content in the yolk at the later stages of embryonic development. These findings suggest that lipolytic enzymes are important in the transfer of lipids from the yolk to the embryo via the circulating fluid, as will be discussed later.

We tried to purify the lipase from the yolk sac and yolk. To find out how the defatting procedure affected the enzyme, we examined the substrate specificity before and after defatting. The ratio of the hydrolysis of olive oil to that of tributyrin by this enzyme did not change after defatting, indicating that the enzyme was not affected by the organic solvents.

Although the purified enzyme had strong specificity toward triglycerides with rather short-carbon-chain fatty acids, the enzyme could also hydrolyze triolein and olive oil, a characteristic of lipase. The lipase activity was not affected by heparin, and the enzyme did not require serum-activated triglyceride as substrate. These facts indicated that the lipolytic enzyme in this study is probably not lipoprotein lipase.

Although the lipase was eluted as a single peak of activity through a Sephadex G-75 column, it gave at least two major bands with $\beta$-naphthylbutyrate hydrolase activity upon polyacrylamide gel electrophoresis, and gave some peaks with tributyrin hydrolase activity upon isoelectric focusing. When the enzyme was treated with neuraminidase, the peaks preparation gave peaks shifted to alkaline $\mathrm{pH}$. These findings suggest that its microheterogeneity arises from differences in the sialic acid content. The similar heterogeneities of lipolytic enzymes were observed in the alkaline lipolytic enzyme of human adipose tissue, ${ }^{12,13)}$ and in the acid lipase in rabbit liver. ${ }^{14)}$

Bengtsson et al. ${ }^{4)}$ suggested that lipoproteins of the yolk were hydrolyzed in the embryonic tissues after passing into the embryonic circulation fluid from the yolk, because they did not detect lipoprotein lipase in the yolk or yolk sac. However, we found that the lipase activity increased in the egg yolk sac and its contents after the 8th day of embryonic development, at which time the lipid content in the yolk were decreasing. Lipolytic enzymes have been studied in relation to the stimulation of lipids in oocytes in the ovary ${ }^{15.16)}$ and may be involved in the transfer of lipoprotein from the circulation fluid into the developing oocyte in the ovary of the laying hen. ${ }^{17)}$ The transfer of lipids from the yolk to the embryo via the circulation fluid during embryonic development seems to be the reverse of that of lipids from the blood into the developing oocyte. Therefore, the egg yolk lipase in this study may be important in the transfer of lipids from the yolk into the egg embryo of Japanese quail.

\section{REFERENCES}

1) R. C. Noble and J. H. Moore, Can. J. Biochem., 42, 1729 (1964).

2) A. G. Goodridge, Am. J. Physiol., 214, 902 (1968).

3) A. J. Evans, C. J. Payne and D. W. Bannister, Int. J. Biochem., 4, 181 (1973).

4) G. Bengtsson, O. Hernell and T. Olivercrona, Int. J. Biochem., 8, 587 (1977). 
5) M. Fujii, Y. Yabu, T. Fukunaga and K. Koga, Int. J. Biochem., 14, 355 (1982).

6) J. Folch, M. Lees and G. H. Sloanestanley, J. Biol. Chem., 226, 497 (1957).

7) K. K. Carroll, J. Lipid Res., 2, 135 (1961).

8) M. Fujii, K. Odawara, T. Fukunaga, K. Koga and H. Tojo, Agric. Biol. Chem., 48, 2197 (1984).

9) J. L. Hedrick and A. J. Smith, Arch. Biochem. Biophys., 126, 155 (1968).

10) O. Hirayama and H. Matsuda, Agric. Biol. Chem., 36, 1831 (1972).

11) M. M. Nachlas and A. M. Seligman, J. Biol. Chem., 181, 343 (1949).
12) J. A. Cortner and J. D. Schnatz, Biochim. Biophys. Acta, 139, 107 (1967).

13) J. D. Schnatz and J. A. Cortner, Biochim. Biophys. Acta, 167, 367 (1968).

14) T. Imanaka, K. Amanuma-Muto, S. Ohkuma and T. Takano, J. Biochem., 96, 1089 (1984).

15) D. A. Gornall, A. Kuksis and N. Morley, Biochim. Biophys. Acta, 280, 225 (1972).

16) P. M. Brannon, A. H. Cheung and A. Bensadoun, Biochim. Biophys. Acta, 531, 96 (1978).

17) J. D. Benson, A. Bensadoun and D. Cohen, Proc. Soc. Exp. Biol. Med., 148, 347 (1975). 